\title{
The importance of positive discipline approach in making students gaın multimedia course content
}

\author{
Mukadder Boydak Özan \\ Faculty of Education, Firat University, Elazig, Turkey. \\ Received 23 December, 2014; Accepted 2 February, 2015
}

\begin{abstract}
In this study, the importance of multimedia contents for effective learning, effective classroom management and building behaviors within the framework of positive discipline approach was emphasized. A questionnaire consisting of 24 items, whose validity and reliability were established, was prepared. The questionnaire was administered to 1474 students from three randomly-selected primary schools situated in the five educational regions in the city center of Elazığ. The gender of the students was considered. As a result of statistical operations carried out, both male and female students agree that multimedia contents contribute positively to effective learning. Even though students of both genders agree with the views concerning classroom management, low results suggest that there are some problems in fulfilling the classroom rules in the classes where multimedia is utilized. It can be said that male students have more positive opinions about the effect of multimedia contents on building behaviors. In-service training courses can be organized for the teachers in respect of classroom management in the course environments where multimedia contents are utilized.
\end{abstract}

Key words: Multimedia contents, effective classroom management, effective learning, student, positive discipline.

\section{INTRODUCTION}

Discipline, which is interpreted in different aspects, is described as regulating or punishing through training and supervising (Gordon, 2000: 4). Humphreys describes it as highly-controlled and partly-controlled behaviors such as shyness, reticence, unassertiveness and avoidance when the care and respect behaviors are taken into account (Humphreys, 1999: 11).

It is important to create a school climate which aims to control students' behaviors and solve their problems; and a climate where students are treated respectfully with positive discipline as a management technique, and where the skills and education required for a successful future are provided. Also, it will be beneficial to create a school climate where students feel confident, through getting the opportunity of learning by means of their own faults in case of failure. In such school climate, students will learn to work together rather than to compete with each other. Students and teachers aim to work on common solutions in compliance with team spirit. If they see themselves as incapable and get discouraged, this will impair the educational environment. Therefore, teachers and students who help each other to create a dynamism climate required for life and learning will provide the conditions for positive discipline (Nelson et

\section{E-mail: mboydak@firat.edu.tr}

Authors agree that this a ricle rema in pemanently open access under the tems of the $\underline{\text { Creative Commons }}$ Attribution License 4.0 Intemational Lic ense 
al., 2000: 11).

Positive discipline approach is affected by the discipline approach existing in the family environment. If the parents love their children unconditionally, meet their creative requirements, spend time with them, enable them to discover the world in different ways, and be patient with them in respect of their faults, then the students will get a sense of responsibility, and leading to the building of the foundations of the positive discipline required in schools (Humphreys, 1999: 89).

Adults are responsible for building positive discipline since they are models for children. Wherever they are, students' self-control is an important step in creating positive discipline. If teachers cannot instill self-control in students, they will expend most of time spent in the classroom to control students. This will affect students' academic success in a negative manner (Çankırılı, 2005).

Positive discipline, which is a management technique for making children responsible individuals and to solve their problems (Nelson et al., 2000:8), enables children to think well of themselves while they learn the rules of the society they live in (Honig and Wittmer, 1991: 65-73). Setting a positive classroom joins together parts of a puzzle. Each part contributes an atmosphere requiring determination, compassion, esteem and mutual respect. (Nelson et al., 2000: 14-175).

Positive discipline focuses on fulfilling a plan which demonstrates accuracy of teaching and emotional motivations of teachers. In practice, while positive discipline is not to misuse the rights of others, it is an approach of school discipline aiding teachers (Canter and Canter 1976: 2).

In positive discipline, teachers encourage their students to understand and follow the rules they propose (Gilman et al., 2009: 310). Positive discipline aims to promote the development of emotion, thought and behaviors, relations between people, and for students to regard themselves with systemic and judgment skills (Kohn, 1996: 12-15; Render et al., 1989: 607-630). Positive discipline emphasizes mostly the social state of belonging.

A Major objective of the educational systems is to provide students with desired behaviors. Desired behaviors can be described in different forms. The case to form the desired behavior can vary as to whether or not the principle view centralizes religion, culture, knowledge, skill and compliance with environment and human (Tural, 2002: 37).

That means desired behaviors can vary from culture to culture, country to country or even nation to nation. It has got a wide range of variety on the functional understanding of "desired behavior".

In educational institutions, undesired problems arising out of the structure, personnel and operation of the organization impede the achievement of organizational purposes. Teachers and managers try to enforce discipline rules in order to overcome such problems (Oğuzkan, 1974: 55).

One of the ways to eliminate discipline problems is to train students on what to do in a given circumstance. The most effective way of reducing or eliminating hindrances causing problems is to form and implement an applicable discipline plan (Aksoy, 2002: 28). Eaton accepts training on problem solving as a way of preventing discipline problems. The first step in providing students with this behavior is to help them learn how to be calm when problems emerge to focus on the respective problem. The second step is to give them opportunities to say what they want to talk about. By means of problem solving techniques, children will learn to value and express their feelings and others' feelings. And they will learn to solve conflicts via positive discipline without resorting to force (Eaton, 1997: 46).

\section{Multimedia content}

Multimedia projects provide students with an opportunity to present a subject in different forms in their own understanding and an explanation through making others to use their ideas (Bennett, 1996: 16). Multimedia renders a powerful communication medium for students; represents new comprehensions within the organized synthesizing and evaluation thereof. Multimedia has the potential of changing student, teacher and roles of interaction between them through enabling students to generate their own interpretations and knowledge (Ivers and Baron, 2002: 2). Also multimedia projects aid motivating learning by means of up-to-date researches which always lead students to investigate and update information in mind (Wolfe, 2001: 3). Multimedia aids learning more and better retention of what was learned (Bagui, 1998: 3-18; Large et al., 1995: 340-342). Multimedia contents are prepared in accordance with the effective learning, cognitive styles and desires of students within the educational system (Ellis, 2001: 23; Lachs, 1998: 57; Rasmussen and Davidson-Shivers, 1998: 291). Student projects enable effective use of technology in the class by means of multimedia contents. Yelland (1999: 39-59) determined three objectives to be fulfilled so as to use the technology in an effective class:

1. Technology and syllabus should comply with each other.

2. Active learning, reinforcing investigation and problem solving environments upgrade levels of thinking skills of students by using in individual and common workings.

3. Media literacy is developed through analyzing the critical use in issues.

\section{The use of multimedia contents in education}

For the last ten years, technological developments have ensured students and teachers develop detailed multimedia contents. Students can make use of different formats so as to express themselves via diverse audio, 
video, graph or animation tools. Though there is a limited number of research in the multimedia fields, multimedia use is promising for teaching and learning (Ayersman, 1996: 25; Cooper, 1998: 93; Liao, 1999: 77; Najjar, 1996: 50; Sivin-Kachala and Bialo, 2000: 23). An effective learning can be supplied with all its levels including students with special needs (Daley, 1999: 23-26; Holzberg, 1998: 52; Pratt, 1999: 28-31; Xin, 1999: 61). Multimedia learning environments support high level of thinking, problem solving (Herrington and Oliver, 1999:21; Oughton and Reed, 1998:63), increased success (Liao, 1999:77; Sivin-Kachala and Bialo, 2000:24) and motivation of students (Marr, 2000: 25; Okolo and Ferretti, 1998: 50-57).

Research revealed that educational materials developed by means of multimedia provide much more powerful learning (Jonassen et al., 1999: 102). However, students taking part in multimedia contents preparation activities facilitates development of their creativity, acquired desired behaviors and content (Liu, 1998: 82).

Although programs are today conducted through using multimedia contents in the Turkish education system, teachers do not exhibit sufficient willingness in this regard. How do we know this? Because, the use of multimedia course content in classroom requires a preliminary preparation and skills. Teachers, who do not have required information about technology, abstain from using multimedia in apprehension of falling behind of syllabus and being embarrassed before students. However, research revealed that the use of multimedia course content forms a learning environment complying with positive discipline understanding and provides significant results in building desired behaviors in comparison with other methods. Cited in this study, the importance of positive discipline approach has been emphasized in terms of providing students with multimedia contents.

For this purpose, the positive discipline approach to multimedia course content in terms of gender;
a. Is it to create significant differences in effective learning?
b. Is it to create significant differences in classroom management?
c. Is it to create significant difference in behavior gain?

\section{METHOD}

This research is a descriptive study, which aims to determine the effects of course content on students. It was conducted via multimedia using the positive discipline approach. Descriptive survey model was used in this research. Descriptive survey model is the research model that describes a past or current situation in the exact way. The individual or object that is the subject of the research is defined as it is and in the exact way. Attempts are not made to change or affect it in any way (Karasar, 1999). Therefore, current situation is reflected. Generally, scale and interview techniques are used in survey researches to collect data (Akdağ, 2010).
Table 1. Demographic characteristics.

\begin{tabular}{|c|c|c|c|c|c|c|}
\hline & \multicolumn{2}{|c|}{ State schools } & \multicolumn{2}{|c|}{ Private schools } & \multicolumn{2}{|c|}{ Total } \\
\hline \multicolumn{7}{|c|}{ Distribution by sex } \\
\hline & $f$ & $\%$ & $f$ & $\%$ & $f$ & $\%$ \\
\hline Male & 634 & 43.01 & 65 & 4.41 & 699 & 47.42 \\
\hline Female & 624 & 42.33 & 151 & 10.25 & 775 & 52.58 \\
\hline \multicolumn{7}{|c|}{ Distribution by grades } \\
\hline & $f$ & $\%$ & $f$ & $\%$ & $f$ & $\%$ \\
\hline Grade 6 & 387 & 26.26 & 96 & 6.51 & 483 & 32.77 \\
\hline Grade 7 & 414 & 28.09 & 69 & 4.68 & 483 & 32.77 \\
\hline Grade 8 & 457 & 31.00 & 51 & 3.46 & 508 & 34.46 \\
\hline Total & 1258 & 85.35 & 216 & 14.65 & 1474 & 100 \\
\hline
\end{tabular}

\section{Universe and sample}

The universe of the research composes of secondary schools students studying in the City Center of Elazig in 2009-2010 education years. The research sample is composed of 1472 secondary school students from 15 primary schools including three schools which were randomly selected out of each education religion in the five education religion. Distribution of students in accordance with gender and type of school where they study is provided in Table 1.

\section{Data collection tool}

A Likert-type questionnaire (regarding effects of the use of multimedia contents on effective learning, classroom management and building behavior) which comprises 24 items and three sections was developed. Opinions of instructors from the field of computer technologies and educational sciences were solicited in order to determine the scope validity of the questionnaire. The questionnaire was finalized through changes and amendments in expression and arrangements made in line with experts' opinions and it was made ready for application in terms of validity and reliability analyses.

$\mathrm{KMO}$ value of the questionnaire prepared was measured as 0.963 . Bartlett test was significant at the level of 0.05 . Results acquired reveal the conformity of data with factor analysis. As a result of the factor analysis, there were no items which had factor load of 0.35 and below. The factor load of materials varies between 0.36 and 0.80 . According to this result, since all materials are operative, no material was excluded from the scale. The Cronbach Alpha reliability coefficient of the scale was founded as 0.92 . The questionnaire was applied to 1500 students to receive their opinions but only 1474 of them delivered their opinions.

\section{Data analysis}

The questionnaires were applied by the researcher and the statistical analysis was performed according to the answers to the questionnaire items.

Independent samples $t$ test was first made, with items handled separately so as to evaluate the data pertaining to the three sections. The gender factor was considered. Independent sample $t$ test was made; items in the lump were evaluated based on gender so as to determine students' opinions. As for the interpretation of questionnaire items, points given are as follows: 4.21-5.00 for "Strongly Agree" alternative; $3.41-4.20$ for "Agree" alternative; 2.61-3.40 for "Undecided" alternative; 1.81-2.60 for "Disagree" alternative; $1.00-1.80$ for "Strongly Disagree" alternative. 
Table 2. It effects on effective learning.

\begin{tabular}{|c|c|c|c|c|c|c|c|c|}
\hline Groups & $\mathbf{n}$ & $\overline{\mathrm{X}}$ & ss & sd & Levene & Sig Level & $\mathbf{t}$ & Sig. Level \\
\hline 1. & \multicolumn{8}{|c|}{ Increases the quality of teaching } \\
\hline Female & 699 & 4.25 & .97 & \multirow{2}{*}{1472} & 05 & \multirow{2}{*}{.83} & \multirow{2}{*}{.63} & \multirow{2}{*}{.53} \\
\hline Male & 775 & 4.23 & .95 & & .05 & & & \\
\hline 2. & \multicolumn{8}{|c|}{ Increase the effectiveness of learning by enriching the content of courses. } \\
\hline Female & 699 & 4.3 & .94 & \multirow{2}{*}{1472} & \multirow{2}{*}{.05} & \multirow{2}{*}{.82} & \multirow{2}{*}{.61} & \multirow{2}{*}{.55} \\
\hline Male & 775 & 4.28 & .93 & & & & & \\
\hline 3. & \multicolumn{8}{|c|}{ Crreates an environment which facilitates learning } \\
\hline Female & 699 & 4.21 & .961 & \multirow{2}{*}{1472} & \multirow{2}{*}{.64} & \multirow{2}{*}{.42} & \multirow{2}{*}{-1.33} & \multirow{2}{*}{.18} \\
\hline Male & 775 & 4.24 & .945 & & & & & \\
\hline 4. & \multicolumn{8}{|c|}{ Multimedia content maintains continuous learning. } \\
\hline Female & 699 & 4.04 & 1.04 & \multirow{2}{*}{1472} & \multirow{2}{*}{.06} & \multirow{2}{*}{.81} & \multirow{2}{*}{.07} & \multirow{2}{*}{.94} \\
\hline Male & 775 & 4.05 & 1.07 & & & & & \\
\hline 5. & \multicolumn{8}{|c|}{ Our motivation is high in the multimedia included lessons } \\
\hline Female & 699 & 4.07 & 1.06 & \multirow{2}{*}{1472} & \multirow{2}{*}{1.54} & \multirow{2}{*}{.22} & \multirow{2}{*}{1.2} & \multirow{2}{*}{.23} \\
\hline Male & 775 & 3.99 & 1.11 & & & & & \\
\hline 6. & \multicolumn{8}{|c|}{ Objectives of the lesson are fully realized by using multimedia content. } \\
\hline Female & 699 & 4.05 & 1.02 & \multirow{2}{*}{1472} & \multirow{2}{*}{.74} & 30 & & \\
\hline Male & 775 & 4.04 & 1.09 & & & .39 & .01 & .99 \\
\hline 7. & Multimec & dia co & ntents & nake u & oncentrate & lessons. & & \\
\hline Female & 699 & 4.03 & 1.12 & 1472 & 20 & ( & 5 & 05 \\
\hline Male & 775 & 3.88 & 1.17 & $14 / 2$ & 2.98 & .08 & 1.95 & .U5 \\
\hline 8. & By the $u$ & Ise of & nultim & dia cor & nt in lesso & learning ta & place i & shorter period \\
\hline Female & 699 & 4.02 & 1.07 & 1472 & 81 & 36 & 2 & 81 \\
\hline Male & 775 & 4.01 & 1.11 & 1412 & .04 & .50 & -.2 & .04 \\
\hline
\end{tabular}

\section{FINDINGS}

Students' opinions concerning effects of the use of multimedia in primary school institutions on effective learning are provided in Table 2.

It is seen that there are no significant differences between the opinions when the eight items specified in the section regarding effects of the use of multimedia on effective learning in classroom environment are analyzed. Both female and male students expressed that they totally agree (Female students: $\bar{X}: 4.21$; male students: $\bar{X}: 4.24)$ with the first, second and third items, indicating "It enhances the quality of education" (Female students: $\bar{X}: 4.35$; male students: $\bar{X}: 4.23$ ), "It increases learning effectiveness through enriching course content" (Female students: $\bar{X}: 4.30$; male students: $\bar{X}: 4.28$ ), "It prepares an environment to facilitate learning" (Female students: $\bar{X}: 4.21$; male students: $\bar{X}: 4.24)$. Both female and male students expressed that they agree with the fourth, fifth, sixth, seventh, eighth items, indicating "Multimedia contents continuously keep learning alive" (Female students: $\bar{X}: 4.04$; male students: $\bar{X}: 4.05$ ), "Our motivation is high in the courses conducted with multimedia contents" (Female students: $\overline{\mathrm{X}}$ : 4.07; male students: $\bar{X}: 3.99$ ), "course aims are totally fulfilled by conducting courses with multimedia contents" (Female students: $\bar{X}: 4.05$; male students: $\bar{X}: 4.04)$, "Multimedia contents aid us to concentrate on the course." (Female students: $\bar{X}: 4.03$; male students: $\bar{X}: 3.88$ ), "Learning is realized in shorter time by means of using multimedia contents in the courses" (Female students: $\bar{X}: 4.02$; male students: $\bar{X}: 4.01)$. Students' opinions concerning the effects of the use of multimedia on classroom 
Table 3. Its effects on classroom management.

\begin{tabular}{|c|c|c|c|c|c|c|c|c|}
\hline Groups & $\mathbf{n}$ & $\overline{\mathrm{X}}$ & ss & sd & Levene & Sig. Level & $\mathbf{t}$ & Sig. Level \\
\hline 9. & \multicolumn{8}{|c|}{ We have a more positive classroom environment in the lessons with multimedia content } \\
\hline Female & 699 & 3.95 & 1.13 & & & & & \\
\hline Male & 775 & 3.92 & 1.19 & $14 / 2$ & .01 & .92 & -.06 & .95 \\
\hline 10. & \multicolumn{8}{|c|}{ It is hard to manage classroom for our teacher in the lessons with multimedia content. } \\
\hline Female & 699 & 3.80 & 1.22 & & & & & \\
\hline Male & 775 & 3.67 & 1.28 & $14 / 2$ & 4.65 & .03 & 1.80 & .00 \\
\hline 11. & \multicolumn{8}{|c|}{ Our motivation is higher in the lessons with multimedia content. } \\
\hline Female & 699 & 4.00 & 1.10 & & & & & \\
\hline Male & 775 & 3.97 & 1.22 & $14 / 2$ & .051 & .82 & -.14 & .89 \\
\hline 12. & \multicolumn{8}{|c|}{ It affects our readiness for the lesson positively } \\
\hline Female & 699 & 4.04 & 1.1 & 1472 & 122 & 27 & 16 & 87 \\
\hline Male & 775 & 4.02 & 1.21 & 1412 & 1.26 & $.2 t$ & .10 & . \\
\hline 13. & \multicolumn{8}{|c|}{ It helps students adopt the rules of the classroom. } \\
\hline Female & 699 & 3.72 & 1.2 & & & & & \\
\hline Male & 775 & 3.70 & 1.27 & $14 / 2$ & $3.4 t$ & .00 & .41 & .69 \\
\hline 14. & \multicolumn{8}{|c|}{ It becomes harder to supervise students in the lessons with multimedia content. } \\
\hline Female & 699 & 3.81 & 1.21 & 1472 & 115 & 28 & -22 & 83 \\
\hline Male & 775 & 3.82 & 2.18 & 1412 & 1.15 &.$\angle 0$ & -.22 & (03,. \\
\hline
\end{tabular}

management are provided in Table 3.

When analyzing the students' opinions about $9^{\text {th }}, 10^{\text {th }}$, $12^{\text {th }}, 13^{\text {th }}$, and $14^{\text {th }}$ items on the effect of using multimedia content on classroom management, it was seen that there was not a significant difference among the following items: "we have more positive classroom environment in the courses in which multimedia are used" (Female students: $\bar{X}: 3.95$; male students: $\bar{X}: 3.92)$, "The control of the classroom by our teacher grows difficult in the courses conducted with multimedia contents" (Female students: $\overline{\mathrm{X}}$ : 3.80 male students; $\overline{\mathrm{X}}: 3.67$ ), "Our motivation is higher in the courses conducted with multimedia contents" (Female students: $\overline{\mathrm{X}}: 4.00$; male students: $\overline{\mathrm{X}}$ : 3.97), "It affects favorably our readiness for the course" (Female students: $\bar{X}: 4.04$; male students: $\bar{X}: 4.02$ ), "It helps students to adopt rules of the classroom" (Female students: $\bar{X}: 3.72$ male students: $\bar{X}: 3.70$ ), and "It hampers controlling students in the courses conducted with multimedia contents." (Female students: $\bar{X}: 3.81$ male students $\overline{\mathrm{X}}: 3.82$ ). All the students stated that they agreed with these views. Although the students indicated that they agreed with these views, their opinions on the $13^{\text {th }}$ item, "It helps students to adopt rules of the classroom" had lower results compared to the other items. According to the results acquired, it can be said that teachers who make use of multimedia in the courses have difficulty in controlling the classroom and students can not get sufficient success in respect of classroom rules.

Results regarding the effects of multimedia contents on students in terms of building behavior dimension are provided in Table 4.

It is seen that there are not any significant differences among students' opinions on the following items: "It aids teachers to have amicable relations with students" (Female students: $\bar{X}$ : 3.84; male students: $\bar{X}: 3.89$ ), "It provides communication facilities for developing teacherstudent interaction" (Female students: $\bar{X}$ : 3.90; male students: $\overline{\mathrm{X}}$ : 3.95), "It ensures students express their feelings overtly" (Female students: $\bar{X}$ : 3.66; male students: $\bar{X}: 3.73$ ), "It helps students to develop positive behaviors" (Female students: $\overline{\mathrm{X}}$ : 3.90; male students: $\bar{X}:$ 3.91), "It enhances social skills of students" (Female students: $\bar{X}: 4.01$; male students: $\bar{X}: 4.10$ ), "It helps students to develop their skills to solve problems and skills required for their whole life" (Female students: $\overline{\mathrm{X}}$ : 4.06; male students: $\bar{X}: 3.93)$, "Multimedia components improve students' skills of creative thinking" (Female students: $\bar{X}: 4.07$; male students: $\bar{X}: 4.20$ ), "It enhances 
Table 4. Building behavior.

\begin{tabular}{|c|c|c|c|c|c|c|c|c|}
\hline Gruplar & $\mathbf{n}$ & $\bar{X}$ & ss & sd & Levene & Sig. Level & $\mathbf{t}$ & Sig. Level \\
\hline 15. & \multicolumn{8}{|c|}{ It facilitates teacher to establish friendly relations with students. } \\
\hline Female & 621 & 3.84 & 1.29 & \multirow{2}{*}{1305} & \multirow{2}{*}{3.411} & \multirow{2}{*}{.065} & \multirow{2}{*}{-.69} & \multirow{2}{*}{.49} \\
\hline Male & 686 & 3.89 & 1.24 & & & & & \\
\hline 16. & \multicolumn{8}{|c|}{ It presents communication opportunities which develops teacher-student interaction. } \\
\hline Female & 621 & 3.90 & 1.21 & \multirow{2}{*}{1305} & \multirow{2}{*}{2.784} & \multirow{2}{*}{.095} & \multirow{2}{*}{-.72} & \multirow{2}{*}{.47} \\
\hline Male & 686 & 3.95 & 1.17 & & & & & \\
\hline 17. & \multicolumn{8}{|c|}{ It helps students reveal their feelings clearly. } \\
\hline Female & 621 & 3.66 & 1.29 & \multirow{2}{*}{1305} & & \multirow{2}{*}{.04} & \multirow{2}{*}{-1.13} & \multirow{2}{*}{.26} \\
\hline Male & 686 & 3.73 & 1.24 & & 4.16 & & & \\
\hline 18. & \multicolumn{8}{|c|}{ It helps students develop positive behaviours. } \\
\hline Female & 621 & 3.90 & 1.22 & \multirow{2}{*}{1305} & \multirow{2}{*}{.7} & \multirow{2}{*}{.40} & \multirow{2}{*}{-.19} & \multirow{2}{*}{.85} \\
\hline Male & 686 & 3.91 & 1.18 & & & & & \\
\hline 19. & \multicolumn{8}{|c|}{ It develops students' social skills. } \\
\hline Female & 621 & 4.01 & 1.19 & \multirow{2}{*}{1305} & \multirow{2}{*}{.09} & \multirow{2}{*}{.77} & \multirow{2}{*}{-1.17} & \multirow{2}{*}{.24} \\
\hline Male & 686 & 4.10 & 1.54 & & & & & \\
\hline 20. & It helps st & udents & develc & proble & solving skil & nd other skill & at they $r$ & ed in their lives. \\
\hline Female & 621 & 4.06 & 2.29 & 1305 & 48 & & 13 & 2 \\
\hline Male & 686 & 3.93 & 1.2 & 1305 & .48 & .49 & 1.3 & .2 \\
\hline 21. & Multimedi & a comp & onents & develop & udents' cre & ve talents. & & \\
\hline Female & 621 & 4.07 & 1.12 & & & & & \\
\hline Male & 686 & 4.20 & 2.13 & 1305 & .18 & .67 & -1.27 & .21 \\
\hline 22. & It helps st & udents & develc & their si & to work in & ups. & & \\
\hline Female & 621 & 3.98 & 1.2 & 1305 & 123 & 27 & 21 & 83 \\
\hline Male & 686 & 3.96 & 1.17 & 1000 & $1 . \angle \mathrm{J}$ & .21 & .21 & (0) \\
\hline 23. & It helps st & udent & learn & he corre & behaviour. & & & \\
\hline Female & 621 & 3.97 & 1.22 & 1305 & 367 & & & 83 \\
\hline Male & 686 & 3.99 & 1.15 & 1305 & 3.01 & .00 &.$- \angle 2$ & .83 \\
\hline 24. & Lessons v & vith mu & Itimedi & conten & velops stu & nts' personal & & \\
\hline Female & 621 & 4.04 & 1.23 & & & & & \\
\hline Male & 686 & 3.99 & 1.24 & 1305 & .01 & .94 & .11 & .48 \\
\hline
\end{tabular}

students' skills for group working" (Female students: $\bar{X}$ : 3.98; male students: $\bar{X}: 3.96)$, "It helps students to learn proper behaviors" (Female students: $\bar{X}$ : 3.97 ; male students: $\bar{X}: 3.99)$, "The courses conducted with multimedia contents improve personal skills of students" (Female students: $\bar{X}: 4.04$; male students: $\bar{X}: 3.99$ ). The students expressed "I agree" on the effects of the use of multimedia contents on building behaviors.
Results of independent samples $t$ test by which items regarding three sections were evaluated in accordance with gender are provided in Table 5. It was not found any significant difference among students' opinions on the level of $p<0.05$.

When analyzing students' opinions about the effect of the use of multimedia course contents on effective learning, classroom management, building behavior, both female and male students expressed that they agree with 
Table 5. Total materials t-test results according to the gender.

\begin{tabular}{|c|c|c|c|c|c|c|c|c|}
\hline Gruplar & $\mathbf{n}$ & $\overline{\mathrm{X}}$ & ss & sd & Levene & Sig. Level & $\mathbf{t}$ & Sig. Level \\
\hline \multicolumn{9}{|c|}{ Effective Learning } \\
\hline $\begin{array}{l}\text { Female } \\
\text { Male }\end{array}$ & $\begin{array}{l}69 \\
77\end{array}$ & & $\begin{array}{l}.81 \\
.75\end{array}$ & 1472 & .43 & .51 & .99 & .3 \\
\hline \multicolumn{9}{|c|}{ Classroom Management } \\
\hline $\begin{array}{l}\text { Female } \\
\text { Male }\end{array}$ & $\begin{array}{l}69 \\
77\end{array}$ & & $\begin{array}{l}.8 \\
.91\end{array}$ & 1472 & 1.23 & .27 & .66 & .51 \\
\hline \multicolumn{9}{|c|}{ Building Behavior } \\
\hline $\begin{array}{l}\text { Female } \\
\text { Male }\end{array}$ & $\begin{array}{l}69 \\
77\end{array}$ & $\begin{array}{l}3.92 \\
3.93\end{array}$ & $\begin{array}{l}.9 \\
.8\end{array}$ & 1472 & 11.60 & .001 & -.15 & .89 \\
\hline
\end{tabular}

the items giving affirmative answers. The highest arithmetic mean (Female: $\bar{X}: 4.12$; Male: $\bar{X}: 4.08$ ) belongs to the effective learning section. According to this result, it brings forth the thought that the use of multimedia contents is important in terms of realization of full learning. Though results were received in respect of "I agree", the lowest arithmetic mean (Female: $\overline{\mathrm{X}}: 3.89$; Male: $\overline{\mathrm{X}}: 3.86$ ) composes of students' opinions pertaining to its effect on classroom management. Even though it was not as high like that of effective learning; female and male students ( $\bar{X}: 3.92 ; \bar{X}: 3.93$ ) expressed that they had agreed with the items by delivering affirmative opinions to building behavior section.

\section{CONCLUSION AND SUGGESTIONS}

In this study, in which the usage of multimedia contents in classroom environment was researched in terms of positive discipline, a questionnaire consisting of 24 items was prepared to receive the students' opinions. Students of both groups expressed that they had agreed with the following items: "It enhances the quality of education", "It increases learning effectiveness through enriching course content" and "It prepares an environment to facilitate learning". According to the results acquired, it can be said that teachers who make use of multimedia in the courses provide full learning environment. Students' opinions resulted in the level of "I agree" with a high arithmetic mean in respect of this section with the item, "Multimedia contents continuously keep alive learning" and other views. When considering how low academic attention span is in the classroom environments in the primary schools, it can be thought that the use of multimedia contents will substantially eliminate such negativeness. While it is nearly impossible to keep students' motivation high in classical classroom environment, students declared that they had agreed with the view "Our motivation is high in the courses conducted with multimedia contents", with a high arithmetic mean. While repetition time students spend in the courses in which classical teaching methods are used is much, it is seen that students have the opinions indicating that the use of multimedia shortens this time in respect with the view "Learning is realized in shorter time by means of using multimedia contents in the courses."

It was not seen any significant differences among students' opinions in terms of the gender in the second section of the questionnaire in which the effects of the use of multimedia contents on the classroom management was researched. Although students stated that they had agreed with the views regarding the effect of the use of multimedia contents on classroom management, it is striking that the lowest arithmetic mean pertains to the views in this section. The view "it aids students to adopt classroom rules" with which students agree in the lowest arithmetic mean, may result in that teachers can not create an exact classroom rule in the course environments where they make use of multimedia.

When analyzing the students' opinions in respect of building behavior section, it is seen that the opinions resulted in the level of "I agree" and there are no significant differences among opinions according to genders. Although students declared that they had agreed with the view "It ensures students to express their feelings overtly" results are lower than other items. It reveals the disadvantages of the technology as well as advantages thereof in the most explicit manner. When analyzing the items "It enhances social skills of students", "Multimedia components improve students' skills of creative thinking", students' opinions resulted in the level of "I agree." However it was seen that results acquired from male students were higher. These results may bring forth the view that male students are more capable in technology and open to it. Students' opinions resulted in the level of "I agree" in a high arithmetic mean in respect of the view "The courses conducted with multimedia contents improve personal skills of students", which is one of the objectives of education with respect to achieving personal success. According to this result, it can be said that conducting the course by means of multimedia contents 
increases individual success.

It was seen that students' opinions concerning eight items in the section pertaining to the effects of multimedia on effective learning increased the effectiveness of the use of multimedia on learning. Therefore, the opinion of students regarding the use of multimedia should be generalized through eliminating the handicaps (technological infrastructure of schools, deficiencies of teachers in the use of multimedia) before the use of multimedia contents in the education.

According to the results acquired from the students' opinions in respect of six items in the section pertaining to its effects on the classroom management, it was seen that the use of multimedia in the courses affected the classroom management adversely. Informative seminars should be given to the teachers in respect of new methods developed about classroom management so as to eliminate such negativeness and make up for teachers' deficiencies regarding classroom management.

Individuals isolate themselves from the social environment they belong to and invent an imaginary world for themselves. Multimedia contents to be used in the education could develop socialization of the students and support such process.

The other result acquired from students' opinions in respect of questionnaire items regarding building behavior is that male students are more open to technology. When taking into account the effectiveness of the usage of multimedia content especially on learning, preparation of such contents in a manner calling female students' attention will make this activity more effective.

\section{Conflict of Interests}

The author has not declared any conflict of interests.

\section{REFERENCES}

Akdağ M (2010). Eğitimde Program Değerlendirme Ve Istatistiksel Yöntemler. http://web.inonu.edu.tr,

Aksoy N (2002). Sınıf Yönetimi, Pegem Yayıncılık, Ankara.

Ayersman DJ (1996). Reviewing the research on hypermedia-based learning. J. Res. Comput. Educ. 28(4):500-25.

Bagui S (1998). Reasons for increased learning using multimedia. J. Educ. Multimedia Hypermedia 7(1):3-18.

Bennett DT (1996). Assessment through video. Electronic Learn. 15(4):16-17.

Canter L, Canter M (1992). Assertive Discipline: Positive Behaviour Management for Today's Classroom, Santa Monica: Lee Canter and Associates.

Cooper SB (1998). Instructor-created computer tutorials for students in an elementary mathematics education course. J. Computi. Childhood Educ. 9(1):93-101.

Çankırılı A (2005). Öğretmen ve Öğrencileri, http://www.zaferdergisi.com/article/? makale=1226, Downloaded on 17.05.2005.

Daley P (1999). Turning the tide. Instructor 108(8):23-26.

Eaton M (1997). "Positive discipline; fostering the self-esteem of young children", Young Children 52:6.

Ellis TJ (2001). Multimedia enhanced educational products as a tool to promote critical thinking in adult students. J. Educ. Multimedia Hypermedia 10(2):107-23.
Gilman R, Huebner ES, Furlong MJ (2009). Handbook of Positive Psychology in Schools, Taylor \& Francis Routledge

Gordon T (2000). Çocukta Dış Disiplin mi? lç Disiplin mi? (Çev:Emel Aksay) İstanbul, Sistem yayıncılık 2. Baskı.

Herrington J, Oliver R (1999). Using situated learning and multimedia to investigate higher-order thinking. J. Educ. Multimedia Hypermedia 8(4):401-21.

Holzberg CS (1998). Helping all learners succeed: Special ed success stories. Technol. Learn. (18)5:52-56.

Honig AS, Wittmer DS (1991). "Socialization and discipline for infants and young children" Early Child Devel. Care. 66

Humphreys T (1999). Disiplin nedir? Ne değildir? (Çev : Berat Çelih) İstanbul Epsilon Yayınları

Ivers KS, Barron AE (2002)., Multimedia Projects in Education Designing, Producing, and Assessing, A Division of Greenwood Publishing Group, Inc. Westport, Connecticut.

Jonassen DH, Peck KL, Wilson BG (1999). Learning with technology: A constructivist perspective. Upper Saddle River, NJ: Prentice-Hall.

Karasar N (1999). "Bilimsel Araştırma Yöntemlerı", Nobel Yayınevi, Ankara.

Kohn A (1996). Beyond discipline: From compliance to community. Alexandria, VA: Association for Supervision and Curriculum.

Lachs V (1998). Making the computer dance to your tune: Primary school pupils authoring hypermedia. J. Comput. Childhood Educ 9(1):57-77.

Large A, Beheshti J, Breuleux A, Renaud A (1995). Multimedia and comprehension: The relationship among text, animation, and captions. J. Am. Society Infor. Sci. 46(5):340-47.

Liao YC (1998). Effects of hypermedia versus traditional instruction on students' achievement: A meta-analysis. J. Res. Comput. Educ 30(4):341-59.

Liao YC (1999). Effects of hypermedia on students' achievement: A meta-analysis. J. Educ. Multimedia Hypermedia 8(3):255-77.

Liu M, Pedersen S (1998). The effect of being hypermedia designers on elementary school students' motivation and learning of design knowledge. J. Interactive Learn. Res. 9(2):155-82.

Marr PM (2000). Grouping students at the computer to enhance the study of British literature. English J. 90(2):120-25.

Najjar LJ (1996). Multimedia information and learning. J. Educ. Multimedia Hypermedia 5(2):129-50.

Oğuzkan F (1974). Eğitim Terimleri Sözlügü̈, Ankara Türk Dil Kurumu Yayını.

Okolo CM, Ferretti RP (1998). Multimedia design projects in an inclusive social studies classroom: Sometimes people argue with words instead of fists. Teach. Exceptional Children 31(1):50-57.

Oughton JM, Reed WM (1998). The effect of hypermedia development on high school students' knowledge acquisition, general problemsolving skills, and general design skills. J. Educ. Multimedia Hypermedia 7(4):333-63.

Pratt B (1999). Making it work. Learn. Lead. Technol. 26(8):28-31.

Rasmussen KL, Davidson-Shivers GV (1998). Hypermedia and learning styles: Can performance be influenced? J. Multimedia Hypermedia 7(4):291-308.

Render GF, Padilla JM, Krank HM (1989). Assertive Discipline: A critical review and analysis. Teachers College Record, 90:607-630.

Sivin-Kachala J, Bialo ER (2000). Report on the effectiveness of technology in schools. 7th ed. Washington, DC: Software and Information Industry Association.

Tural N (2002). "Öğrenci Başarısında Etkili Okul Değişkenleri ve Eğitimde Verimlilik" Eğitim Bilimleri Fakültesi Dergisi. Ankara: Ankara Üniversitesi Eğitim Bilimleri Fakültesi Yayını, Cilt: 35, Sayı: 1.

Wolfe P (2001). Brain matters: Translating research into classroom practice. Alexandria, VA: Association for Supervision and Curriculum Development. 1999: 39-59.

Xin JF (1999). Computer-assisted cooperative learning in integrated classrooms for students with and without disabilities. Inform. Technol. Childhood Educ. Annual. 61-78.

Yelland N (1999). Reconceptualizing schooling with technology for the 21st century: Images and reflections. Inform. Technol. Childhood Educ. Annual. 